\title{
Application of green building concept in the basement area of indonesia computer university
}

\author{
Herman S. Soegoto ${ }^{1, *}$, and Wanita Subadra Abioso ${ }^{1}$ \\ ${ }^{1}$ Universitas Komputer Indonesia, Bandung, Indonesia
}

\begin{abstract}
One of the aspects that need to take into consideration in the matter of constructing the building, particularly multi-storey building is the aspect of power efficiency that would be used mainly for the utilization of electrical energy. The building Engineer will attempt to fulfill the building owner expectation by creating designs for the building that may help to save more energy as well as lowering the operating cost. The objective of this research is analysing benefits and costs from the construction of a building by taking into account energy efficiency aspects with applying a case study to three basement unit which is located in Universitas Komputer Indonesia. This research using quantitative analysis to evaluate the installation and energy cost saving of the basement air circulation system and equipment. The result indicates that the building especially the basement area where the air circulation is quite good and a precise air fan on-off control system could reduce the cost of electricity from the continuous operating of exhaust fan and fresh air blower.
\end{abstract}

\section{Introduction}

\subsection{Research background}

The development of the design field in Indonesia is getting better as can be seen from various aspects, such as building aesthetics, building functions, building strength, building compliance with government regulations and also electricity consumption efficiency. Nowadays every government as well as private institution seeks to operate at the lowest possible cost and also to be environmentally friendly. One of the efforts undertaken, among others, is by designing energy efficient buildings.

According to IPCC's Fourth Assessment Report on Climate 2007, the world's buildings consume more than $1 / 3$ of the world's resources for their construction, use $40 \%$ of the world's total energy, $12 \%$ of total clean water supply, produce $40 \%$ of the total greenhouse emission, and in 2030 , it is estimated that $1 / 3$ of the world's total emission will come from buildings [1]. Energy use for ventilation and infiltration is significant and can account for one third to one half of the total space conditioning energy [2]. Building energy uses account for approximately $40 \%$ of total primary energy use in developed countries. Of this, the residential sector uses 60 to $70 \%$ for space conditioning [3].

The Indonesian government's policy regarding building construction refers to Law Number 28 of Year 2002 and Government Regulation Number 36 of Year 2005 on the implementation of Law Number 28 of Year 2002. Whereas the green building concept is established in the Regulation of Minister of Public Works Number 2 of Year 2015 on Green Buildings.

Every building constructed since the establishment of the Regulation of the Minister of Public Works has to comply with the stipulation set in the regulation. This regulation has in fact benefitted building owners and users, particularly in terms of improved efficiency in energy, material and resources use.

The construction of the new 16-floor campus building of the Indonesia Computer University that was completed in 2017 has from the beginning adopted the green building concept from its design stage to its construction up to its operation stage. The university paid a lot of attention to the efficiency of resources used in its construction, which include the use of proper yet competitively cost efficient material, its pleasing and attractive aesthetics so that it has a distinctively unique appearance compared to other campuses in general, efficiency in the use of land and yards for green space, efficiency in its electricity consumption by installing energy-efficient equipment's, and automatic operation system for air conditioners, lifts, lighting units, and fans that can be set to operate automatically according to operational hours.

In this research, one of the green building aspects that is going to be analyzed is the concept of air circulation in the basement that is used for motorcycle parking.

\footnotetext{
* Corresponding author: herman@unikom.ac.id
} 


\subsection{Aims of research}

This research aims to:

- Analyze the benefits of air ventilation wall opening in the basement area;

- Analyze the electricity cost savings from operating automatic timer fans.

\section{Literature review}

Green building is a concept that refers to a building that applies improved efficiency in its use of resources, such as energy, water, and the material used, to reduce the negative impacts of its construction on humans and the environment. Green building criteria include: site management, energy use efficiency, water use efficiency, material and resources use efficiency, quality and comfort management, and operation management [4]. Green Building is defined as the practice of (1) increasing the efficiency with which buildings and their sites use energy, water, and materials, and (2) reducing building impacts on human health and the environment, through better siting, design, construction, operation, maintenance, and removal-the complete building life cycle [5].

The practice of creating structures and using processes that are environmentally responsible and resource-efficient throughout a building's life-cycle from siting to design, construction, operation, maintenance, renovation and deconstruction. This practice expands and complements the classical building design concerns of economy, utility, durability, and comfort. Green building is also known as a sustainable or 'high performance' building [6]. The Building Construction Authority rates building according to five key criteria: energy efficiency, water efficiency, environmental protection, indoor environmental quality, and other green and innovative features that contribute to better building performance [7]. It is necessary to provide a ventilation system to a building to fullfill fresh air requirement for the people and theirs activity. Ventilation provides exchange of polluted air for fresh outside air or clean air from neighboring room [8]. Ventilation is supply to and removal of air from a space to improve the indoor air quality [9].

\section{Research methods}

This research uses a combination of quantitative and qualitative method. The descriptive analysis of the qualitative method is used to analyze the benefits of optimizing the basement wall opening for air ventilation; the quantitative method is used to determine the amount of electricity consumption cost savings that result from the use of fresh air intake and exhaust fan.The data of electricity consumption efficiency are analyzed using the following equation: $\mathrm{C}_{\mathrm{ost}}=$ load cost $* \mathrm{kw}+\beta * \mathrm{kw}^{*} \mathrm{t} * \mathrm{~d}$,

$\mathrm{C}_{\text {ost }}=$ Electricity cost

$\beta=$ electricity cost $/ \mathrm{kwh}$

$\mathrm{kw}=$ motor fan kilowatt

$\mathrm{t}=$ fan operation time (hours) $\mathrm{d}=$ operation day for a month

\section{Results and discussion}

\subsection{Analysis of air ventilation on the basement wall}

The Indonesia Computer University building has 16 floors, 3 bottom floors of which are the basement used for parking. The other 13 floors above them are used for offices, laboratories and classrooms.

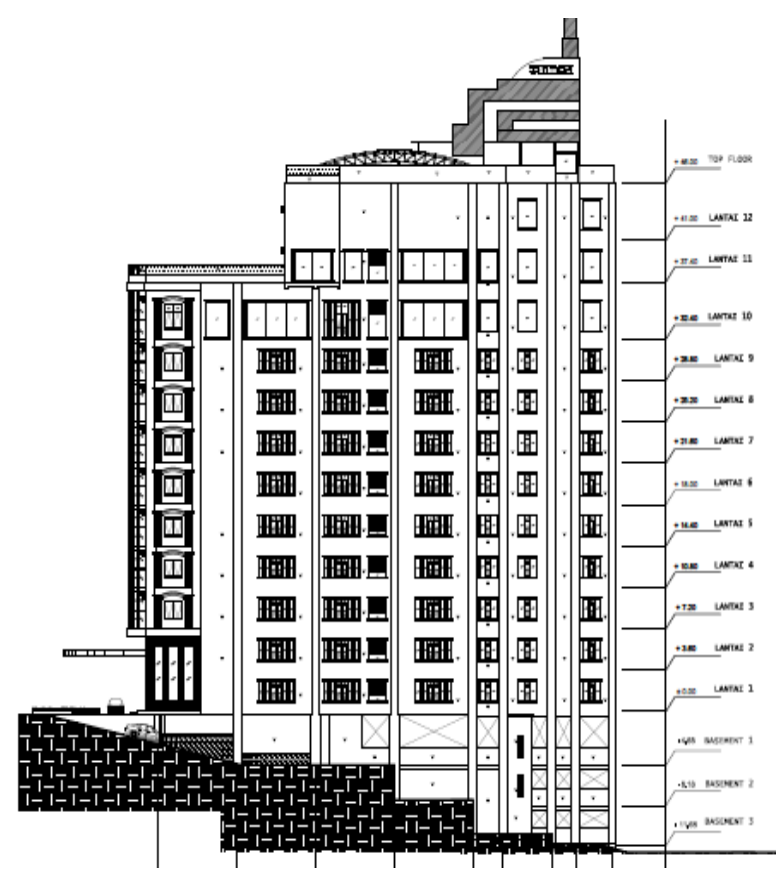

Fig. 1. South facade of the building.

Basement walls 1, 2, and 3 in the west side are closed because they are located under the ground. For basement 1 north and south, there is a large opening because most of the basement is located above the ground. The east wall, however, is bordered by the canteen.

Basement 1 is used for car parking area and student canteen. Air opening on the walls of basement 2 and basement 3 is designed differently because they have different land contours. These basements are used for students' motorcycle parking and have nearly the same parking capacity because they have the same floor width. The north, east and south basements are closed because they are located under the ground level. The east wall has a larger air ventilation opening compared to that of basement 3 .

However, because there is a large wall opening for air circulation provided by the car ramp in the north and south side, so basement 1 is using natural ventillation system. Natural ventilation uses the natural forces of wind and buoyancy to introduce fresh air and distribute it effectively in buildings for the benefit of the occupants [10]. This system is sufficient to supply fresh air for the basement 1, no intake or exhaust fan is needed. The ventilation effectiveness depends on the air distribution and the location of the pollution sources in the space [9]. 
Because basement 2 has a larger fresh air wall opening than that of basement 3 , it is equipped only with 1 unit of exhaust fan to suck and blow away carbon monoxide gas catched in the basement area. For fresh air supply, it uses a wall opening in the east side with a window of $63 \mathrm{~m}^{2}$.

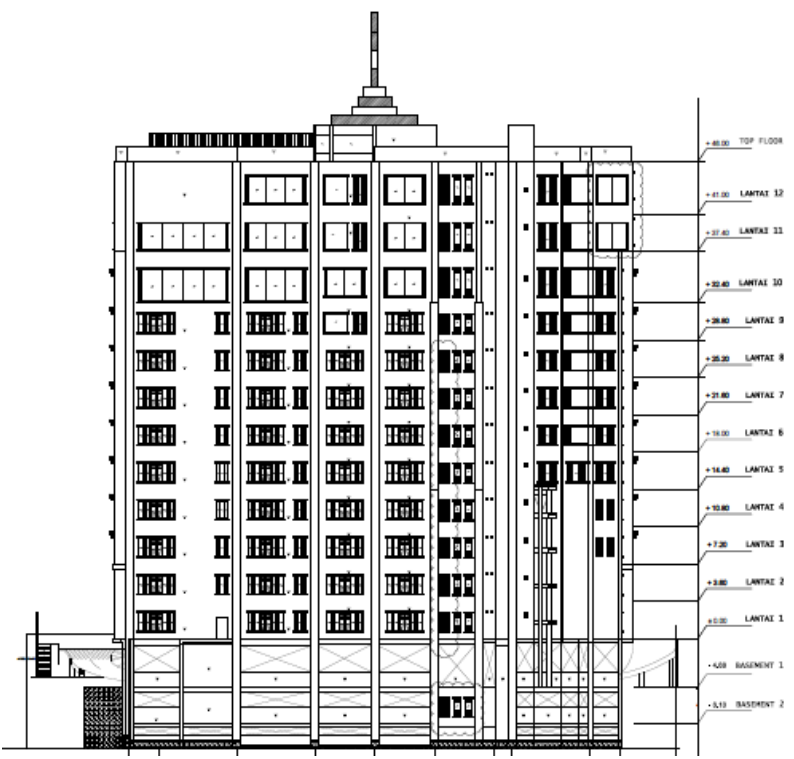

Fig. 2. East facade of the building.

Basement 3 has a smaller fresh air wall opening compared to that of basement 2, with an opening of about $14 \mathrm{~m}^{2}$ wide. Therefore, basement 3 is only equipped with 1 unit of exhaust to blow away $\mathrm{CO}$ gas and 1 unit of air intake fan to supply fresh air to the basement.

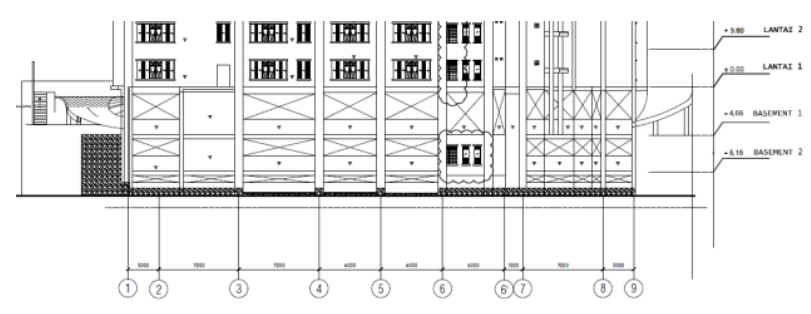

Fig. 3. South facade of basements 1, 2, dan 3 .

\subsection{Intake and Exhaust Fan Analysis}

Basement 2 uses 1 unit of exhaust fan to suck and blow away carbon monoxide gas trapped in the basement area. The fan has the capacity of 25420 CFM and uses a 4000 watt electric motor.

Based on Figure 4, it can be seen that the air ducting position is installed along the area where it is expected to suck gas trapped in the basement through the existing 12 exhaust shafts.

Basement 2 is operated from 6 am until $10 \mathrm{pm}$. The amount of operational cost if the fan is continously operated between those hours or for 14 hours times the per kwh electricity price of Rp 1035.78/kwh charged by the State Electricity Company (PLN) can be obtained through the following formula:
The cost incurred without the use of timer with the assumption that the fan is operating for 14 hours per day, or 336 hours per month, or 4032 hours per year, is Cost $=$ load cost $+1036 * 4 * 4032=$ Rp. $16,708,608$ of total electricity cost per year.

Electric load cost for Social Business kategory $\mathrm{S} 3 \mathrm{~K} / 86500 \mathrm{VA}$ is $\mathrm{Rp} 29500 / \mathrm{kva}$. Based on this reference the total installation load cost for UNIKOM is 86.5 $\mathrm{kva} /$ month or $69.2 \mathrm{kw} / \mathrm{moth}=\mathrm{Rp} 25.517 .500$, or Rp. $368.750 / \mathrm{kw} /$ month. Cost fan $\mathrm{B} 2=368,750 * \mathrm{kw}+1036 * \mathrm{kw}^{*} \mathrm{t} * \mathrm{~d} ;$
$\mathrm{t}=$ operating hours; $\mathrm{d}=$ day; $\mathrm{kw}=$ kilowatt of fan

$$
\begin{aligned}
\text { Cost } / \text { month } & =368,750 * 4+1036 * 4 * 14 * 24 \\
& =\operatorname{Rp} 2,867,384,-
\end{aligned}
$$

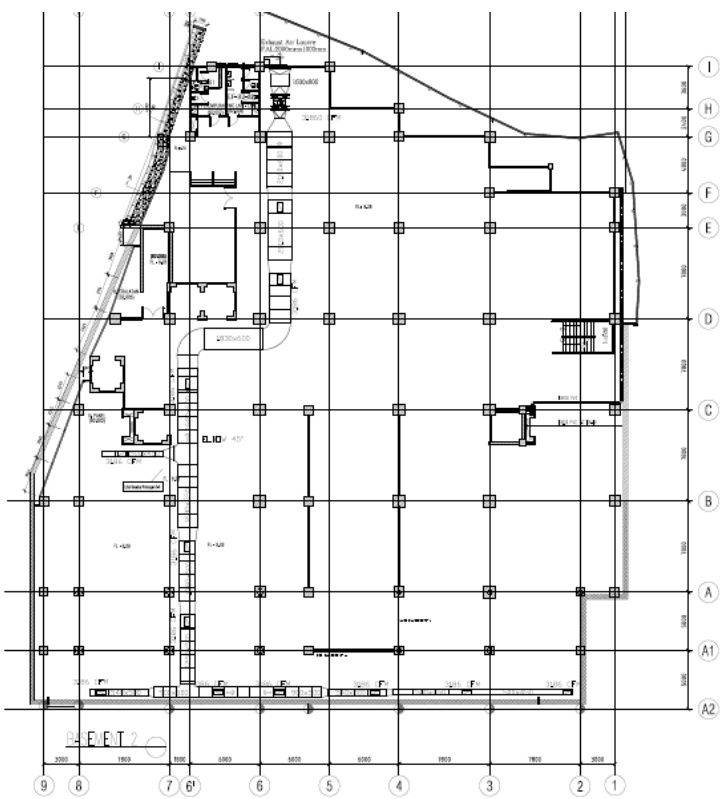

Fig. .4. Layout of basement 2 and air ducting channel.

In practice, in order to economize the electricity use, an automatic timer has been installed in the fan to make it operate only during the peak hours when students' motorcycles go into the basement area, that is between 8:00 and 10:00 am. Outside those hours, incoming and outgoing vehicle traffic is not much, therefore the air ventilation in the east side of the basement is considered capable of handling the air exchange, particularly in getting rid of the $\mathrm{CO}$ gas inside. With this procedure, the electricity cost incurred for the operation of exhaust fan in basement 2 for 1 month period is: Cost $=368,750 * 4+$ $1036 * 4 * 2 * 24=$ Rp. $1,673,912$. Hence, it results in a saving of Rp. 1,193,472.- of operational cost per month, or Rp. 14,321,664,- for a year.

Basement 3 is equipped with a 5500 watt electric motor powered exhaust and fresh air intake fan with a supply \& exhaust capacity of 31860 CFM. The layout of basement 3 fan position and ducting is shown in Figure 5 above. Fresh air intake ducting is positioned in the shouth side, whereas the exhaust fan is positioned in the

Cost $=$ load cost $+1036 * \mathrm{kw}^{*} \mathrm{t}$ 
north side. Its operation time is the same as that in basement 2 , that is 14 hours.

If both fans were operated for 14 hours, the electricity consumption cost would be:

$$
\begin{aligned}
\text { Cost/month } & =\text { load cost*kw+1036*kw*t*d } \\
& =368,750 * 11+1036 * 11 * 14 * 24 \\
& =\text { Rp.7,885,306,-- }
\end{aligned}
$$

Basement 3 fan is operated only from 07.00-09.00 am. All students' motorcycles entering the basement from 6.00 am are directed by the security to basement 3 first. The peak density of basement 3 takes place between $06.45-09.00 \mathrm{am}$. There is not much motorcylcle traffic in basement 3 outside those hours. Therefore, air circulation can make use of the east side window of the basement. The daily electricity cost with the timer that automatically operates the fan only for 2 hours per day is: Cost $=368,750 * 11+1036 * 11 * 2 * 24=$ Rp 4,603,258,-

The savings from electricity operational cost for 1 month is Rp.3,282,048,- or Rp. 39,384,576,- for a year.

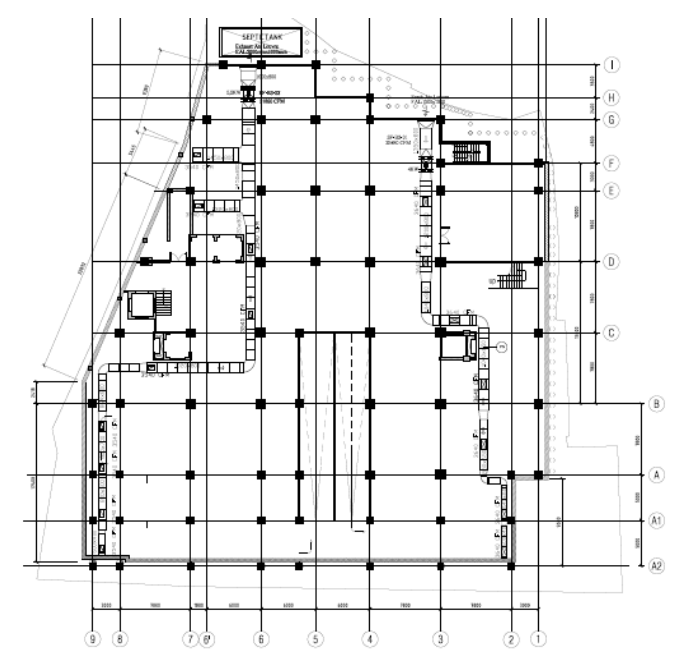

Fig. 5. Layout of basement 3 and air ducting channel.

The total electricity cost savings for a year from basement 2 and basement 3 with timer-operated fans is Rp 53,706,240.-

The total material (motor starter, mcb, and cable) and installation cost is less than Rp. 4,000,000,-. So based on the cost consideration it is worthed to install timer controller for the fan.

The total cost reduction is about $58.38 \%$ compare to continous operation during the working hours. This cost reducing is higher comparing with the research conducted by Rudd which stated that by operating the system intermittently as opposed to continuously, estimated a $28 \%$ annual savings in total energy use [11].

However, there is still a handicap with this timer controller system. It still needs an operator to turn off the switch on Saturday afternoon so that the fans will not operate during the scheduled hours on Sunday.

\section{Conclusions}

Based on the anlysis above, it can be concluded that:

- Basements designed with sufficient windows for air ventilation can reduce or even minimize the electricity cost that is associated with the continuous operation of fans during the basement operational time.

- Timer-controlled fan operation time that meets the need of fan operation will significantly reduce the annual electricity cost.

- Timer fan does still have a weakness because it operates everyday during the same hours. On Sundays, where there is no activity in the basement, this can be a waste if the operator forgets to turn off the automatic fan system. Therefore, it is necessary to make an additional system that can turn off the fan on Sundays.

Rector of Indonesia Computer University who is very concern to build a green and energy efficient building with a beautiful campus facade. The construction project team who working together with the writer as one solid construction team from design stage until construction complete.

\section{References}

1. https://www.ipcc.ch/pdf/assessmentreport

2. M.H. Sherman, N. Matson., "Ventilation-Energy Liabilities in U.S. Dwellings," In Proceedings 14th AIVC Conference: Energy Impact of Ventilation and Air Infiltration, Coventry, Great Britain:Air Infiltration and Ventilation Centre pp. 23-39 (1993)

3. M. Orme, Energy Impact of Ventilation: Estimates for the Service and Residential Sectors. AIVC Technical Note 49 (Air Infiltration and Ventilation Center, 1998)

4. A. Widjanarko, Pohon \& Green Building (Sekertaris Jendral Kementrian Pekerjaan Umum Indonesia, 2013)

5. Office of the Federal Environmental Executive, the federal commitment to green building: experiences and expectations, available at http://www.ofee.gov/sb/fgb_report.asp.

6. EPA, Green Building, available at http:/www.epa.gov/greenbuilding/pubs/about.htm.

7. BCA, Building Construction Authority 3rd Green Building Masterplan, avalaible at https://www.bca.gov.sg/GreenMark/others/2nd_Gr een_Building_Masterplan.pdf

8. D. Adamovsky, Building Ventilation System. Department of Microenvironmental and Building Service Engineering.

9. D. Bienfait, K. Fitzner, T. Lindvall, O. Seppanen, Guidelines for Ventilation Requirements in Building. Commission of European Communities (Directorate General for Science, Research and Development, 1992) 
10. T. Yang, C. Croome, C. Natural Ventilation in Built Environment https://www.researchgate.net/publication/30197506 근

11. A. Rudd, Air Distribution Fan and Outside Air Damper Recycling Control (Heating Air Conditioning and Refrigeration News pp. 45, 1999) 